\title{
Analysis of Reduction of Authority of The Constitutional Court Through The Law on General Election
}

\author{
Budiman N.P.D Sinaga ${ }^{{ }^{*}}$ and Sahat H.M.T Sinaga ${ }^{2}$ \\ ${ }^{1}$ Faculty of Law, Nommensen HKBP University, Medan, Indonesia \\ ${ }^{2}$ School of Postgraduate Studies, Parahyangan Catholic University, Bandung, Indonesia
}

\begin{abstract}
In the 1945 Constitution of the Republic Indonesia, there is an order to further regulate in the Law such as the general election that has been enacted Law No. 7/ 2017 on General Election. In its Law, the results of the general election is merely a dispute over the result of the general election regarding the determination of the vote which may affect the election participants' seats and the President and Vice President election results. The objective of this paper is to find out the legal consequences of the provisions of the law which reduce the authority of state institutions that have been regulated in the 1945 Constitution. The approach of this research is status approach that will be used by examining the laws and regulations relating to the problem. The provisions of the Law on General Elections can be said to have reduced the authority of the Constitutional Court granted the Constitution. There should be strong grounds for an amendment to this provision it can be done immediately by the House of Representatives and the President. Testing by the Constitutional Court may be done but it is better through changes by the House of Representatives and the President.
\end{abstract}

\section{Introduction}

The amended 1945 Constitution changes radically provisions concerning the Judicial Power. [1] The revised of the amended 1945 Constitution consist of more comprehensive provisions dealing with judicial power. In addition to provide the existence of Supreme Court and its powers, the amended 1945 Constitution also provided the existence of the Constitutional Court. Article 24 of amended Constitution states as follows:

(1) Judicial power is an independent power to administer juridical proceedings in order to uphold law and justice.

(2) Judicial power is exercised by one Supreme Court and others its subordinate judiciaries in the ordinary court jurisdiction, religion court jurisdiction, military court jurisdiction, and administrative court jurisdiction, and that by the Constitutional Court.

(3) Other judiciaries whose function concerning judicial power is prescribed in law.

Paragraphs (1) and (2) od Article 24C of the amended 1945 Constitutiona state:

(1) The Constitutional Court is competent to try to verify the compatibility of law with the Constitution at the first as well as last instance whose decisions is conclusive, to settle jurisdictional conflict between state organs whose competencies provided by the Constitutions, to settle the disolution of political party, and to settle conflict over the result of general election.

\footnotetext{
*Corresponding Author : budiman.sinaga@uhn.ac.id
} 
(2) The Constitutional Court is obliged to judge upon the House of Representatives opinion about suspicion of breaching Constitution by the President and/or Vice President.

The state institutions established and the authority granted by the 1945 Constitution are constitutional organs. [3] The constitutional provisions concerning Constitutional Court are further implemented by Act Number 24 of 2003 on Constitutional Court. Article 10 of the Law specifies:

(1) The Constitutional Court holds jurisdiction of first and final instance, whose decisions shall be final:

a. To review a law against the 1945 Constitution of the Republic of Indonesia;

b. To resolve disputes of jurisdiction between state institutions whose competencies are defined by the 1945 Constitution of the Republic of Indonesia;

c. To pass decisions on the dissolution of political parties; and

d. To resolve disputes involving the results of the general elections.

(2) The Constitutional Court is obliged to pass a decision on the opinion of the DPR which alleges that the President and/or the Vice-President has committed a violation of the law in the form of treason against the state, engaged in corruption, bribery, committed other serious criminal offences or misconduct, and/or no longer fulfils the requirements to be a President and/or Vice-President as prescribed by the 1945 Constitution of the Republic of Indonesia.

(3) The provisions referred to in paragraph (2) consist of:

a. Treason against the state, which constitutes a criminal offence against the security of the state as prescribed by law;

b. Corruption and bribery, which constitute criminal offences of corruption and bribery as prescribed by law.

c. Other serious criminal offences, which constitute criminal acts punishable by a prison sentence of 5 (five) years or more.

d. Misconduct is an act which undermines the dignity of the President and/or the VicePresident.

e. Non-fulfillment of the requirements to be President and/or Vicepresident which constitutes a condition as defined in Article 6 of the 1945 Constitution of the Republic of Indonesia.

From the formulation of the articles above it can be seen that the Constitutional Court has the authority to examine and decide on disputes concerning the results of general elections at all levels and all types of general elections Dari rumusan pasal-pasal di atas dapat dilihat bahwa Mahkamah Konstitusi berwenang memeriksa dan memutus perselisiha tentang hasil pemilihan umum pada semua tingkatan dan semua jenis pemilihan umum. [4]

'Politicians, public figures or anyone aspiring for a public office may now have a new way of achieving their ambitions through a legal battle in court... The requirements are simple and reasonably easy to meet. First, get a political party to nominate you; secondly, contest the election result if you happen to loose [sic] and; thirdly, enlist people who have enough guts to testify (or perhaps to lie) under oath that your rivalshave robbed you of your election victory either by illegally inflating their vote tally or preventing your supporters from casting their votes... Do not worry about the validity of their testimonies; the honorable judges will not bother to verify them. The fact that the testimonies are given under oath means they must be true... As for you supporters who did not cast their votes, the judges will take care of them. Once you have submitted "all of the requirements", just sit back and wait for your inauguration. [5]

On August 16, 2917 Law Number 7 of 2017 concerning General Elections (Election Law) was promulgated. Through this Act, it has been put together and simplified Law Number 42 
of 2008 concerning General Elections of the President and Vice President, Law Number 15 of 2011 concerning General Election Organizers, and Law Number 8 of 2012 concerning General Elections of Members of the House of Representatives, The Regional Representative Council and the Regional People's Legislative Assembly become a law as the legal basis for the general election simultaneously.

Crucial issues in the Election Bill are the threshold for presidential elections, parliamentary thresholds, or parliamentary threshold, seat allocation for DPR members per electoral district, and electoral system. In addition, there are still a number of things that are carefully considered because they are different provisions from the previous provisions, including disputes over election results. In Article 473 the Election Law is mentioned:

(1) Disputes over election results include disputes between KPU and Election Contestants regarding the determination of the vote acquisition results on national elections.

(2) Disputes over the determination of vote results from the election of members of the DPR, DPD, and DPRD nationally include disputes over the determination of votes which can affect the acquisition of seats for Election Contestants.

(3) Disputes over the determination of vote results from the election of the President and Vice

President on a national basis include disputes over the determination of votes which can influence the determination of the results of the Election of the President and Vice President.

From the above provisions it can be seen that disputes over the acquisition of election results include disputes over the determination of votes which can affect the acquisition of seats in the DPR, DPD and DPRD and affect the determination of the results of the Election of the President and Vice President. This provision has limited the disputes over election results only regarding the acquisition of votes which can affect the results of the acquisition of seats and the determination of the results of the Election of the President and Vice President.

Provisions that can be said to be the same are found in Law Number 10 of 2016 concerning the Second Amendment to Law Number 1 of 2015 concerning the Stipulation of Government Regulation in Lieu of Law Number 1 of 2014 concerning the Election of Governors, Regents, and Mayors into Laws (Local Election Law). Article 156 of the Election Law states:

(1) Disputes over Election results constitute disputes between Provincial KPU and /or Regency/City KPU and Election participants concerning the determination of vote acquisition results from the Election.

(2) Disputes over the determination of votes for the results of the Election as referred to in paragraph [1] are disputes over the determination of a significant vote acquisition and may affect the determination of elected candidates.

Although the above is said that the provisions in these two Laws can be said to be the same but still allow differences of opinion in the implementation due to the use of words or several different words, especially "significant" and "influential". If reading these Articles alone, it is not clear the reason for submitting an application for cancellation of the determination of the results of vote counting by the KPU to the Constitutional Court. In other words, these two laws have not provided legal certainty.

Based on the above provisions, the dispute over the determination of the acquisition results of the election results is only a dispute in determining the acquisition of a significant amount of assets and can affect the determination of the elected candidates. The authority of the Constitutional Court is regulated in Article 24C Paragraph (1) of the 1945 Constitution: The Constitutional Court is competent to try to verify the compatibility of law with the Constitution at the first as well as last instance whose decisions is conclusive, to settle jurisdictional conflict between state organs whose competencies provided by the 
Constitutions, to settle the disolution of political party, and to settle conflict over the result of general election.

From the description that has been submitted, there can be found several problems related to the request for cancellation of the determination of the results of vote counting by the KPU to the Constitutional Court. However, on this occasion only will be discussed about, whether the Law may reduce the authority of state institutions regulated in the Constitution?

\section{Objective of the Study}

The objective of this paper is to find out the legal consequences of the provisions of the law which reduce the authority of state institutions that have been regulated in the 1945 Constitution.

\section{Methodology}

To achieve the objective of making this paper, the approach of legislation (status approach)[1] will be used by examining the laws and regulations relating to the problem.

\section{Discussion}

The problems raised above are open to be discussed and resolved with various sciences including Legal Sciences and even branches of Law. However, this opportunity will only be discussed from the point of view of Indonesian Constitutional Law and Constitutional Law. Constitutional law is a body of law which defines the role, powers, and structure of different entities within a state, namely, the executive, the parliament or legislature, and the judiciary; as well as the basic rights of citizens and, in federal countries such as the United States and Canada, the relationship between the central government and state, provincial, or territorial governments. [6]

Constitutional law is [1] That branch of the public law of a state which treats of the organization and frame of government, the organs and powers of sovereignty, the distribution of political and governmental authorities and functions, the fundamental principles which are to regulate the relations of government and subject, and which prescribes generally the plan and method according to which the public affairs of the state are to be administered. [2] That department of the science of law which treats of constitutions, their establishment, construction, and interpretation, and of the validity of legal enactments as tested by the criterion of conformity to the fundamental law. [3] A constitutional law is one which is consonant to, and agrees with, the constitution; one which is not in violation of any provision of the constitution of the particular state. [7]

The Basic Law is the most important legal source in a country. However, not all things can be subject to content in the Constitution so that it must be regulated in other laws and regulations which are domiciled under the Constitution. The types of legislation that are most suitable for further regulating the material content that has been regulated in the Constitution are the Law. Even some content material has been intentionally further regulated in the Act as found in Article 22A of the 1945 Constitution.

In Article 22A of the 1945 Constitution, it is stated that further provisions concerning the procedure for the formation of laws are regulated by law. In connection with these provisions, Law Number 12 of 2011 concerning the Establishment of Legislation (UUP3) has been implemented. Therefore, every formulation of laws and regulations cannot be separated from the provisions in this UUP3. 
Content of the Laws and Regulations is material contained in the Legislation in accordance with the types, functions, and hierarchies of the Legislation. The Law is a Law that is established by the House of Representatives with the joint agreement of the President. The 1945 Constitution of the Republic of Indonesia is the basic law in the Laws and Regulations. According to Article 5 of UUP3, in forming the Laws and Regulations must be carried out based on the principle of Establishing good laws and regulations, which include:

a. clarity of purpose;

b. appropriate institutional or official establishment;

c. suitability between type, hierarchy and content material;

d. can be implemented;

e. efficacy and usefulness;

f. clarity of formulation; and

g. openness

In connection with the issues that will be discussed in this paper, it is deemed necessary to provide an explanation of some of the principles above as stated in the Elucidation of the Law. What is meant by "appropriate institutional or official principle" is that every type of legislation must be made by a state institution or official Establishing an Authorized Legislation. These laws and regulations can be canceled or null and void if they are made by state institutions or unauthorized officials.

What is meant by "the principle of conformity between types, hierarchies, and content material" is that in the Establishment of Legislation must really pay attention to the content material that is appropriate in accordance with the type and hierarchy of the Legislation.

What is meant by "the principle of clarity of formulation" is that each Legislation must meet the technical requirements for the preparation of Legislation, systematics, choice of words or terms, as well as clear and easy to understand legal language so as not to cause various interpretations in its implementation.

Then in Article 6 paragraph (1) of this Law it is said that the material of the contents of the Legislation must reflect the principle:

a. guarding;

b. humanity;

c. nationality;

d. kinship;

e. nationality;

f. Unity in Diversity;

g. justice;

h. equal position in law and government;

i. order and legal certainty; and/or

j. balance, harmony and harmony.

The content material that must be regulated by the Law based on UUP3 Article 10 contains:

a. further regulation regarding the provisions of the 1945 Constitution of the Republic of Indonesia;

b. command of a Law to be regulated by Law;

c. ratification of certain international agreements;

d. follow up on the decision of the Constitutional Court; and / or

e. fulfillment of legal needs in society.

In addition, the content of the material that must be regulated by the Law is a follow-up to the decision of the Constitutional Court.

The use of different terms or the use of several terms for the same purpose can complicate the implementation and even cause problems. Actors in the Indonesian law are not required to have a legal education background, for example members of the Election Supervisory 
Body. Even though their duties are very closely related to the implementation of laws and regulations, even in the context of sanctions, some positions that require legal education are still often causing problems in the implementation of the Law.

Law enforcement is considered as a form of enforcement of the constitution given the aspects that are carried out in law enforcement are enforcement of the constitution. [9] In addition, one important legal principle is lex supeior derogat legi inferiori. Based on this principle, the lower law must not contradict the higher law.

\section{Conclusions and recommendations}

Until now there is still material found in the Law which reduces the authority of state institutions that have been regulated in the Constitution as regulating the Constitutional Court. Whereas the Constitutional Court is a judicial institution that functions as the guardian of constitution.In addition there are still several laws that use different terms for the same purpose so that it can be said that there is legal uncertainty. This kind of legal uncertainty opens up opportunities for problems to arise in the implementation of the Law. Therefore, it needs to be clearly regulated that the authority of state institutions that have been regulated in the constitution must not be reduced through the Law.

\section{References}

1. P. M. Marzuki, Penelitian Hukum, 136, (Prenada Media, Jakarta, 2014).

2. P. M. Marzuki, An Introduction To Indonesian Law, 124, (Setara Press and Zaidun \& Partners Counselors \&Attorneys at Law, Malang, 2011).

3. M. Mas, Hukum Konstitusi dan Kelembagaan Negara, 209, (Rajagrafindo Persada, Depok, 2018).

4. Fatkhurohman, D. Aminudin, Sirajuddin, Memahami Keberadaan Mahkamah Konstitusi di Indonesia, 51, (Citra Aditya Bakti, Bandung, 2004).

5. Simon Butt,Indonesian Constitutional Court decisions in regional head electoral disputes, CDI Policy Paper, 2013/01. Access this CDI Policy Paper online@www.cdi.anu.edu.au

6. https://en.wikipedia.org/wiki/Constitutional_law

7. https://thelawdictionary.org/constitutional-law/

8. M. Junaidi, Hukum Konstitusi, Pandangan dan Gagasan Modernisasi Negara Hukum, 164, (Rajawali Pers, Depok, 2018). 